\title{
Työnohjauksesta on moneksi
}

Kaarina Ranne, Heikki Markkanen \& Tuula Malo (toim. 2011).

Työnohjaus ryhmien ja organisaatioiden kehittämisen

välineenä. TAMK, 235 sivua.
TYÖNOHJAAJAKSI voi kouluttautua Suomen eri puolilla, niin yliopistojen, ammattikorkeakoulujen kuin erilaisten yhdistystenkin organisoimissa koulutuksissa. Teoksen toimittajista Kaarina Ranne ja Heikki Markkanen ovat toimineet Tampereen ammattikorkeakoulun työnohjaajakoulutuksen pääkouluttajina. Kirja sisältää yhteensä 20 artikkelia, joista puolet on tiivistetty työnohjaajakoulutuksessa tehtyjen lopputöiden pohjalta artikkeleiksi. Loput artikkelit edustavat sellaisten henkilöiden näkemyksiä työnohjauksesta, jotka oman työnsä, tutkimuksen tai kouluttajan tehtävänsä vuoksi ovat työnohjauksen asiantuntijoita. Vastaavanlaisia työnohjaajakoulutuksen oppimisen antia kuvaavia toimitettuja teoksia on Suomessa ilmestynyt kymmenkunta.

Teoksen nimi tiivistää keskeisen sisällön hyvin tuodessaan esille työnohjauksen ryhmien ja organisaatioiden kehittämisen välineenä. Samalla nimi paljastaa, että kirjan sisältö on laaja ja moninainen, jopa hajanainen, mutta moninaisuudessaan teos pystyy antamaan kuvauksen työnoh- jauksen monista sovellusmahdollisuuksista. Työnohjauksella voidaan kehittää organisaatioita ja työyhteisöjä, vaikuttaa työterveyshuollon ja työsuojelun muuttuneen roolin jäsentämiseen, aktivoida koulutusten kehittämiseen, auttaa traumojen kohtaamisessa, tukea työuran alkutilanteissa ja syventää niin opettajan kuin urheiluvalmentajan ammatillisuutta.

Teos sisältää myös useita kiinnostavia työnohjauksen menetelmällisen kehittämisen kuvauksia, aina menetelmän historiallisesta lähtökohdasta tulevaisuuden haasteisiin. Draama, narratiivisuus, kehollisuus, kuvataiteet ja taideterapia antavat uusia menetelmäsovelluksia työnohjaukseen. Artikkeleissa on myös työnohjauksen keskiöön sijoittuvien käsitteiden kuvausta, kuten transferenssi-ilmiön, tunteiden ilmenemisen, hiljaisen tiedon ja monikulttuurisuuden.

\section{URHEILUVALMENNUKSESTA MONIKULTTUURIRYHMIIN OHJAUKSEEN}

Kirjan sisältö on rikas ja monipuolinen. Teos antaa työnohjauksesta kuvan monitieteisenä, monella tavalla toteutettavana ja useita ammattisektoreita palvelevana työmuotona. Erityisen vahva uutuusarvo on urheiluvalmennuksen ja työnohjauksen keskinäisen sisällön kuvauksessa. Samoin monikulttuuristen ryhmien työnohjauksen erityiskysymyksistä on vielä kovin vähän kirjoitettu.

Kirjan eduksi voi nostaa sen sisällön monipuolisuuden, mutta kritiikiksi artikkeleiden tasoerot. Vahvaa tieteellistä argumentaatiota ja runsasta lähdekirjallisuutta on hyödynnetty Arto Kallioniemen artikkelissa monikulttuuristen työnohjausryhmien erityiskysymyksistä. Artikkeli on sisällöltään em teemasta niin monipuolinen kuvaus, että kokenut työnohjaaja saattaisi artikkelin auttaman jäsennyksen avulla rohkaistua vetämään monikulttuurista työnohjausryhmää, vaikkei olisi aiemmin toiminutkaan monikulttuurisuuden kanssa.

Muita kirjan "helmiä" ovat PiaMaria Gardbergin kuvaus tunteista työnohjauksessa. Artikkelissa pohditaan, miten työnohjaaja voi auttaa ohjattavaa omien työtunteidensa säätelyssä ja hyväksynnässä tai jäsentää ohjattavan tunneko- 
kemuksia mielen joustavuuden ja tunneäly -käsitteiden avulla.

Jyrki Veistämö pohtii artikkelissaan kokeneen työnohjaajan hiljaisen tiedon olemusta ja merkitystä. Työnohjaus on aina luottamuksellista toimintaa, tapahtuu suljettujen ovien takana ja huomattavan abstraktilla tasolla. Tätä kontekstia ajatellen on ymmärrettävää, että työnohjaajan osaaminen on vaikeasti tunnistettavaa ja siksi lähtökohtaisesti työnohjaajan hiljaisen tiedon jäsentäminen on erinomainen pohdittava teema.

Veistämö tekee työnohjaajan hiljaista tietoa näkyvämmäksi muiden muassa kuvaamalla työnohjaajan erilaisiin rooleihin sisältyvää osaamista. Kokenut työnohjaaja siirtyy työnohjauksen kuluessa joustavasti roolista toiseen ollen välillä tutkijan, opettajan, konsultin tai arvioijan rooleissa. Näissä kaikissa Veistämön kuvaamissa työnohjaajan rooleissa hiljaisen tiedon käyttö on erilaista.

\section{OPPIMISMENETELMIÄ}

Työnohjaajakoulutusten pedagogiikkaa on avattu kirjoittamalla kovin vähän. Kaarina Ranteen artikkeli Tampereella toteutetun työnohjaajakoulutuksen kuvauksesta paikkaa tätä puutetta erinomaisesti. Tutkiva oppiminen ja ryhmästä saatava emotionaalinen tuki ovat kuvatun koulutuksen rakenteellisia ratkaisuja, joilla pyritään monipuoliseen ja syvälliseen työelämän ilmiöiden tunnistamiseen sekä omakohtaisten työnohjaustyössä läpi käytävien tunteiden turvalliseen analysointiin. Aikuisopiskelijalle on haaste omaksua uusia teoreettisia käsitteitä niin elävästi ja syvällisesti, että ne auttavat työnohjaajana jäsentämään aina vain monimutkaistuvamman työelämän erilaisia tilanteita ohjattavan hyödyksi.

Artikkelissa kuvattu round table -oppimismenetelmä palvelee uusien käsitteiden omaksumisessa. Samoin erittäin mielenkiintoinen kuvattu menetelmä on opitun ankkurointi, jolla tarkoitetaan koulutusjakson jälkikäteen tapahtuvaa reflektiivistä analysointia, jonka vuorollaan kukin työnohjaajakoulutettava toteuttaa suullisesti ryhmän sosiaaliseksi pääomaksi. Tämä menetelmä edistää sekä yksilöllistä että kollektiivista oppimista.
Työnohjausmenetelmällisistä artikkeleista haluan nostaa erityisen ansiokkaina esille Annukka Häkämiehen kuvauksen draamasta työnohjauksessa. Artikkelin monipuolinen sisältö ja runsas lähdemateriaali antavat vakuuttavan kuvan em menetelmän sovellusarvosta. Samoin Satu Hintikan artikkeli trauman kohtaamisesta työnohjauksessa on seikkaperäinen kuvaus trauman kokonaisvaltaisesta kehollisesta kokemuksesta. Artikkelin rikas lähdekirjallisuus auttaa lukijaa tutustumaan aiheeseen vielä syvällisemmin.

Vaikka työnohjaajakoulutusten lopputöistä on tarjolla useita toimitettuja artikkelikirjoja ja vaikka tässä arvioimani teos sisältää eri tasoisia artikkeleita, olen silti vakuuttunut siitä, että kirja monipuolisuudessaan toimii hyvin niin työnohjaajaksi kouluttautuvien oppimateriaalina kuin jo alalle valmistuneille täydennyskoulutusmateriaalina.

Soili Keskinen kasvatustieteen professori työnohjaaja ja työnohjaajien kouluttaja

Rauman opettajankoulutuslaitos Turun yliopisto 